\title{
KAJIAN KUALITAS STREETSCAPE DI KORIDOR JALAN PEMUDA BLORA
}

\author{
Sintia Dewi Wulanningrum \\ Dosen Prodi S1 Arsitektur, Jurusan Arsitektur dan Perencanaan, Fakultas Teknik, \\ Universitas Tarumanagara, Jakarta \\ e-mail: sintiaw@ft.untar.ac.id
}

\begin{abstract}
ABSTRAK
Koridor di Jalan Pemuda Blora merupakan koridor utama di Kabupaten Blora, pada koridor Jalan Pemuda terdapat fungsi perdagangan dan jasa, fungsi perkantoran, hunian, pelayanan umum dan khusus, serta terdapat deretan bangunan-bangunan lama, peninggalan kolonial dan arsitektur Cina. Streetscape di koridor jalan Pemuda saat ini masih kurang menampilkan identitas kawasan, oleh sebab itu diperlukan penelitian terkait streetscape di koridor Jalan Pemuda. Metode penelitian yang dipakai adalah kualitatif deskriptif, untuk mengidentifikasi koridor di Jalan Pemuda dan menganalisis streetscape koridor di Jalan Pemuda. Tujuan penelitian yaitu untuk menganalisis kualitas fisik eksisting pada koridor Jalan Pemuda. Berdasarkan hasil analisis, menunjukkan bahwa eksisting streetscape di koridor Jalan Pemuda masih kurang dapat menampilkan karakter kawasan seperti kurangnya elemen perabot jalan.
\end{abstract}

Kata kunci : Jalan Pemuda, Koridor, Streetscape

\section{ABSTRACT}

The corridor on Jalan Pemuda Blora is the main corridor in Blora Regency, on the Jalan Pemuda corridor there are trade and office functions, residential, residential, and special functions, as well as old buildings, colonial heritage and Chinese architecture. Streetscape in the Jalan Pemuda corridor currently still does not show the identity of the area, therefore research related to the streetscape in Jalan Pemuda corridor is needed. The research method used is descriptive qualitative, to identify the corridor on Jalan Pemuda and analyze the view of the corridor on Jalan Pemuda. The research is to analyze the existing physical quality of the Jalan Pemuda corridor. Based on the analysis, it shows that the street scenery in the Jalan Pemuda corridor is still unable to display the character of the area such as the lack of street furniture elements.

Keywords: Corridor, Pemuda Street, Streetscape

\section{PENDAHULUAN}

Pada saat ini koridor Jalan Pemuda telah berkembang menjadi sebuah koridor komersial yang memiliki beberapa bangunan baru dengan gaya arsitektur modern, serta bangunan lama yang memiliki gaya Arsitektur Kolonial dan Cina. Pada bangunan pelayanan fungsi khusus, seperti: Rumah Dinas Wakil Bupati, Markas Polisi Militer, Kantor Satuan Lalu Lintas Kabupaten Blora, Kantor Komando Distrik Militer, Cafe (Ex.Seruni) yang merupakan bangunan peninggalan Belanda. Selain itu, terdapat pula

PAWON: Jurnal Arsitektur, Nomor 01 Volume VI, Januari - Juni Tahun 2022, ISSN 2597-7636 
bangunan komersial yang digunakan untuk kegiatan perdagangan dan jasa seperti; Rumah Makan Citra Minang, Toko Sumber Makmur, Toko Prima, Toko Panca Logam, serta rumah toko (ruko) lainnya peninggalan kebudayaan Tionghoa.

Sebuah kawasan ataupun wilayah koridor jalan dikenal dengan adanya ciri khusus yang dimiliki oleh segala elemen pembentuknya. Selain itu, pembentukan visual streetscape perkotaan diharapkan dapat menceritakan karakter dan image dari kota tersebut, mulai dari cerita historisnya, hingga gaya hidup perkotaan yang tercermin dari fasilitas dan aktivitas yang terlihat pada streetscape (Anugrah, 2015). Bahkan kekhasan yang dimiliki oleh masing-masing koridor dapat membantu manusia dalam mengorientasikan dirinya ketika berada di suatu wilayah tertentu (Rizqiah, 2016). Namun streetscape di sepanjang koridor Jalan Pemuda masih kurang menampilkan identitas kawasan, seperti kurangnya perabot jalan yang mampu merepresentasikan karakter kawasan, dan juga kurangnya elemen perabot ruang, seperti; tempat sampah, bangku taman atau bench, kurangnya guiding blok. Penelitian terkait koridor Jalan Blora telah dilakukan sebelumnya yang berjudul Tipologi Fasad Pada Koridor Jalan Pemuda Sisi Selatan (Wulanningrum, 2021), pada penelitian ini menganalisis tipologi pada koridor sisi selatan, meliputi; tipologi atap, dinding, bukaan dan signages. Selain itu, penelitian terkait streetscape telah dilakukan sebelumnya antara lain : Historic Streetscape Characterization: Exploring the Evolution of Street in the Malay Royal Town (Ismail, 2019), Streetscape Beautification, Penggunaan Patung Pada Lanskap Jalan Di Provinsi Bali (Wardiningsih, 2018), oleh sebab itu penelitian terkait streetscape merupakan judul penelitian yang menarik untuk dibahas karena streetscape dapat merepresentasikan karakteristik serta kualitas kawasan.

Tujuan penulisan artikel yaitu untuk mengkaji kualitas streetscape kawasan di koridor Jalan Pemuda.

\section{TINJAUAN PUSTAKA}

Istilah koridor secara fisik dapat diartikan sebagai sebuah organisasi ruang linier sedangkan secara non-fisik dapat diartikan sebagai sebuah sistem tautan atau keterkaitan (Moughtin, 2003). Sedangkan menurut Krier (1979) Koridor merupakan jalur pergerakan penduduk dengan ruang yang ditentukan oleh pola, fungsi, sirkulasi, serta dinding yang membatasi yang mana dapat berupa bangunan.

\section{Tipe Bentuk Koridor}

Tidak ada standar baku yang membagi tipe jalan secara pasti. Banyak jalan yang sudah didesain dan dibangun yang akhirnya disukai, dijadikan sebagai bahan tulisan, dan diabadikan (difoto), tetapi analisa mengenai bentuk jalan masih sedikit dihasilkan (Moughtin, 1992). 
Terdapat dua tipe jalan secara fisik (Moughtin, 1992) antara lain :

1) Jalan yang dibentuk oleh kompleksitas bangunan disekitarnya (blocks).

2) Jalan yang terbentuk sebagai dampak tiga dimensional bangunan yang ada disekitarnya dan di dalamnya terdapat ruang terbuka dan lansekap.

Streetscape adalah istilah yang digunakan untuk menggambarkan alam dan binaan, dan didefinisikan sebagai kualitas desain jalan dan efek visualnya, terutama bagaimana area beraspal ditata dan dirawat. Streetscape meliputi; bangunan, permukaan jalan, dan juga perlengkapan dan perlengkapan yang memudahkan penggunaannya dari halte bus dan tanda untuk skema penanaman (Rehan, 2013).

\section{Elemen-Elemen Streetscape}

Menurut Rehan (2013) Elemen-elemen streetscape antara lain; trotoar, pohon dan tepi landsekap; street furniture (seperti ; bangku, pencahayaan, tempat sampah, signages), persimpangan, sudut jalan, median jalan, fasilitas sepeda, halte bis, public art dan ruang kafe atau ruang toko.
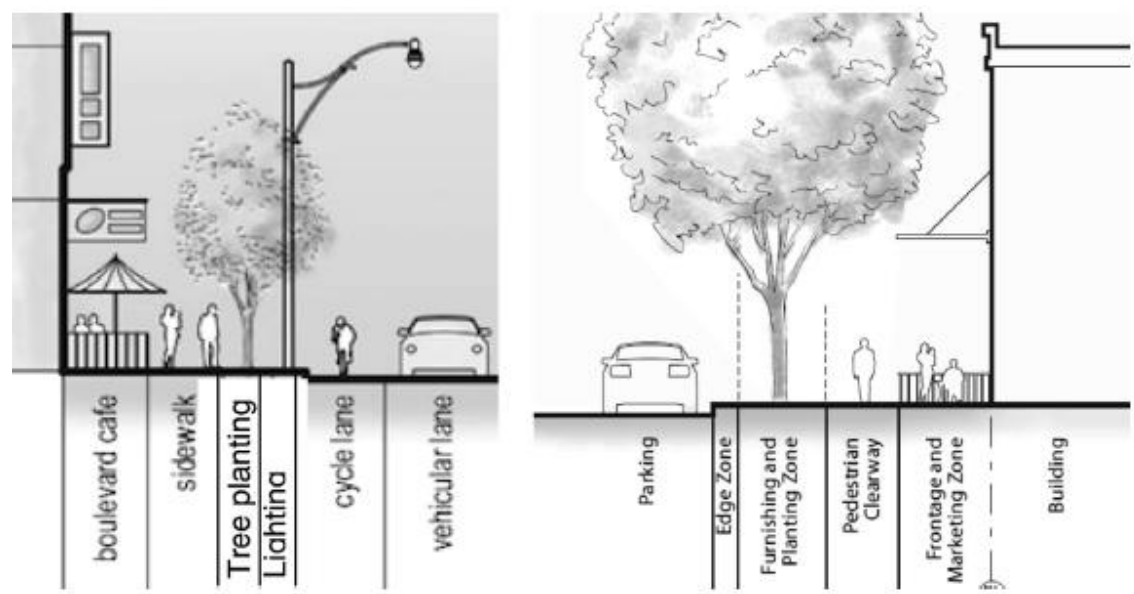

Gambar 1. Potongan Streetscape

Sumber : Reihan, 2013

\section{METODE PENELITIAN}

Metode penelitian yang digunakan adalah kualitatif deskriptif untuk mengidentifikasi streetscape koridor di Jalan Pemuda dan menganalisis streetscape koridor di Jalan Pemuda. Sedangkan pendekatan Grounded research digunakan untuk merumuskan fenomena-fenomena yang ada di streetscape koridor di Jalan Pemuda. Teknik pengumpulan data pada penelitian diperoleh melalui observasi atau pengamatan pada streetscape 
koridor di Jalan Pemuda, serta berasal dari literatur buku dan jurnal yang berkaitan dengan koridor dan streetscape kawasan.

\section{HASIL DAN PEMBAHASAN}

Lokasi penelitian berada di Jalan Pemuda, Kabupaten Blora, dengan panjang koridor sekitar 1,2 Kilometer. Jalan Pemuda terletak di sebelah timur Alun-alun Kota Blora. Jalan Pemuda merupakan jalan utama di Kabupaten Blora dan merupakan jalan utama di kabupaten Blora karena berada di pusat kota Blora. Pada koridor di Jalan Pemuda terdapat fungsi vital seperti kantor pemerintahan, sosial, perdagangan dan jasa, serta hunian yang mendapat pengaruh dari arsitektur Kolonial, Cina, dan Modern (gambar 2).

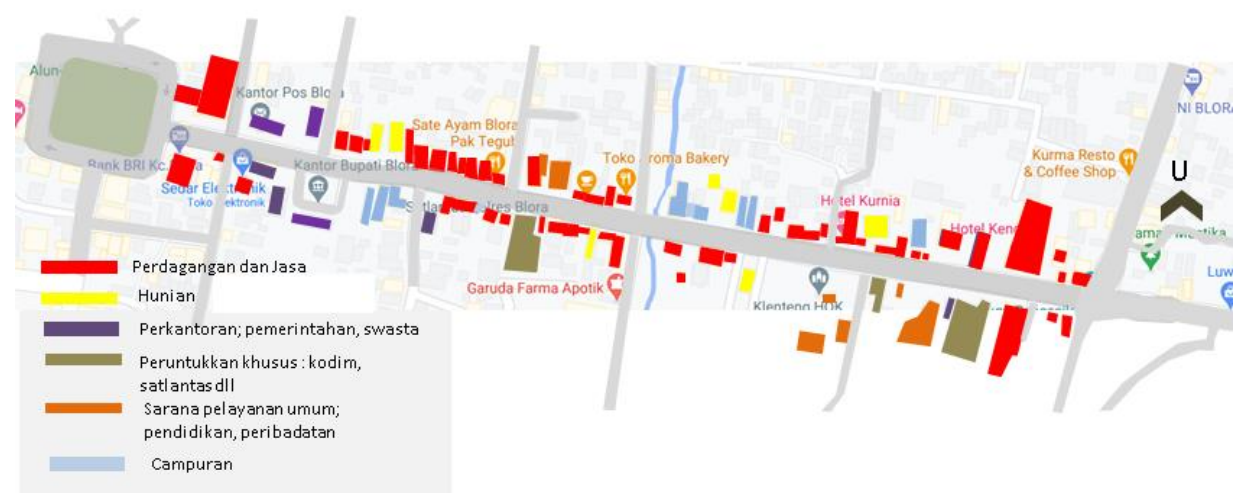

Gambar 2. Lokasi koridor Jalan Pemuda Sumber : google maps dan olahan penulis , 2021 


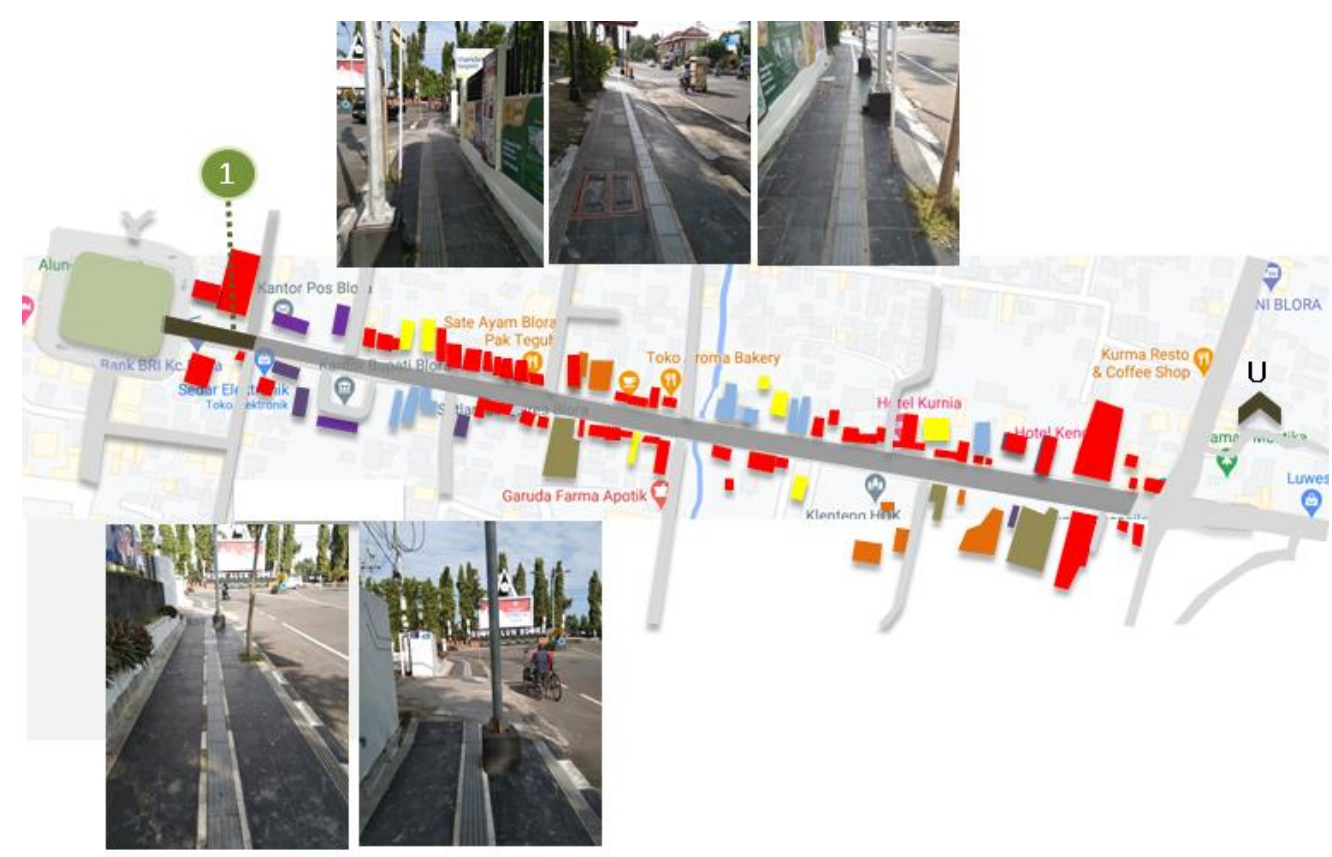

Gambar 3. Koridor Jalan Pemuda (bagian 1)

Sumber : dokumentasi pribadi, google maps dan olahan penulis, 2021

Pada koridor bagian 1, jalur pejalan kaki sisi utara dan sisi selatan memiliki lebar jalur yaitu $210 \mathrm{~cm}$ serta memiliki paving blok berbentuk persegi panjang pada bagian tengah jalur pejalan kaki terdapat guiding blok berwarna abu-abu dengan lebar $30 \mathrm{~cm}$, selain itu tidak pada koridor sisi ini, untuk pepohonan sangat kurang terutama dibagian selatan (gambar 3).

PAWON: Jurnal Arsitektur, Nomor 01 Volume VI, Januari - Juni Tahun 2022, ISSN 2597-7636 


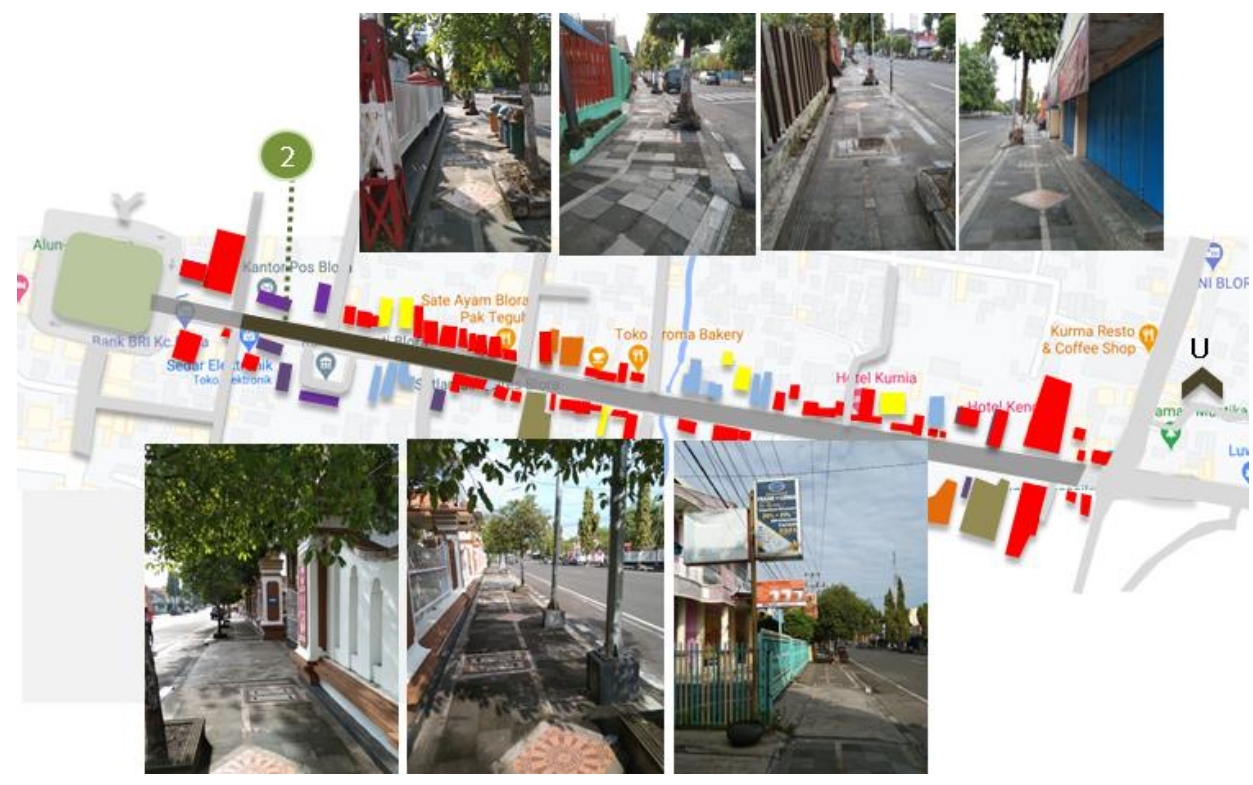

Gambar 4. Koridor Jalan Pemuda (bagian 2)

Sumber : dokumentasi pribadi, google maps dan olahan penulis, 2021

Pada koridor Jalan Pemuda bagian 2, lebar jalur pejalan kaki sisi utara $225 \mathrm{~cm}$, serta terdapat paving blok dan pohon. Paving blok pada jalur pejalan kaki berwarna abu-abu, serta pada bagian tengah jalur pejalan kaki terdapat motif paving blok berwarna orange, berbentuk bujur sangkar. Pada jalur pejalan kaki terdapat sidewalk dengan lebar $20 \mathrm{~cm}$ (gambar 4). 


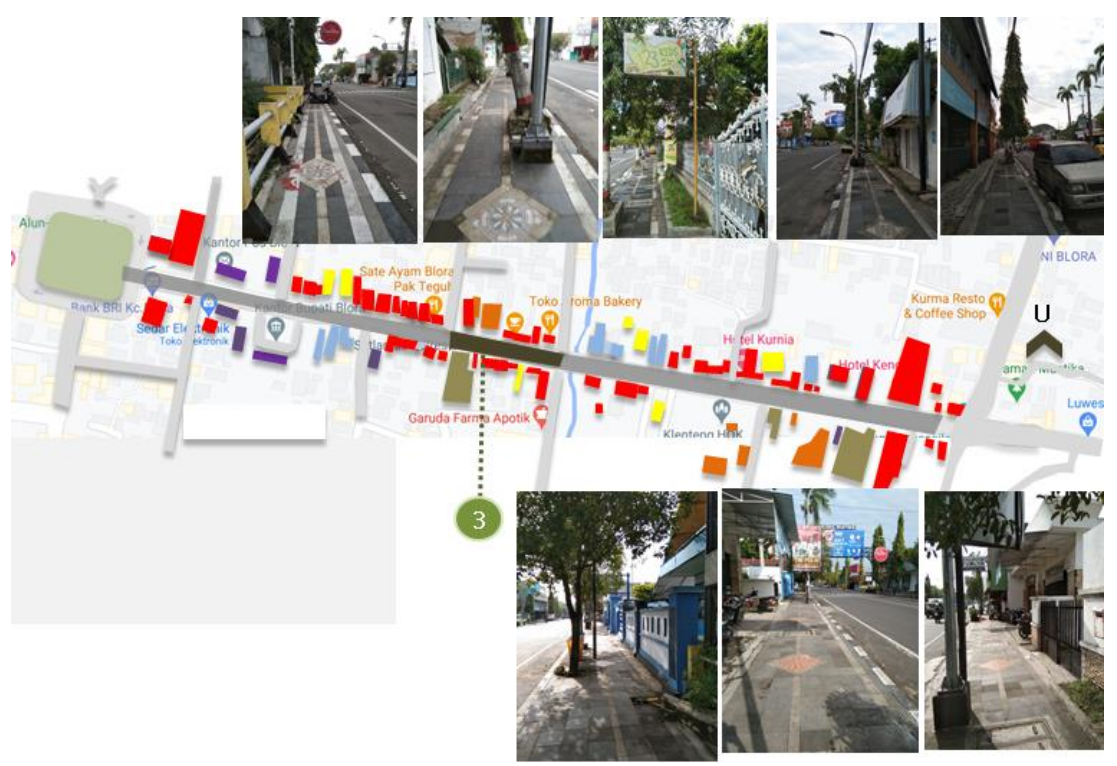

Gambar 5. Koridor Jalan Pemuda (bagian 3)

Sumber : dokumentasi pribadi, google maps dan olahan penulis, 2021

Pada koridor Jalan Pemuda bagian 3, lebar jalur pejalan kaki sisi utara dan selatan adalah $220 \mathrm{~cm}$, material jalur pejalan kaki yaitu paving blok warna abu-abu, serta terdapat juga sidewalk dengan lebar $20 \mathrm{~cm}$. Lebar jalur pejalan kaki pada koridor bagian 3 cukup luas, akan tetapi tidak terdapat guiding block (gambar 5). Pada koridor bagian 3 tidak terdapat pembatas pengaman seperti bollard yang memisahkan jalur pejalan kaki dengan jalan raya. 


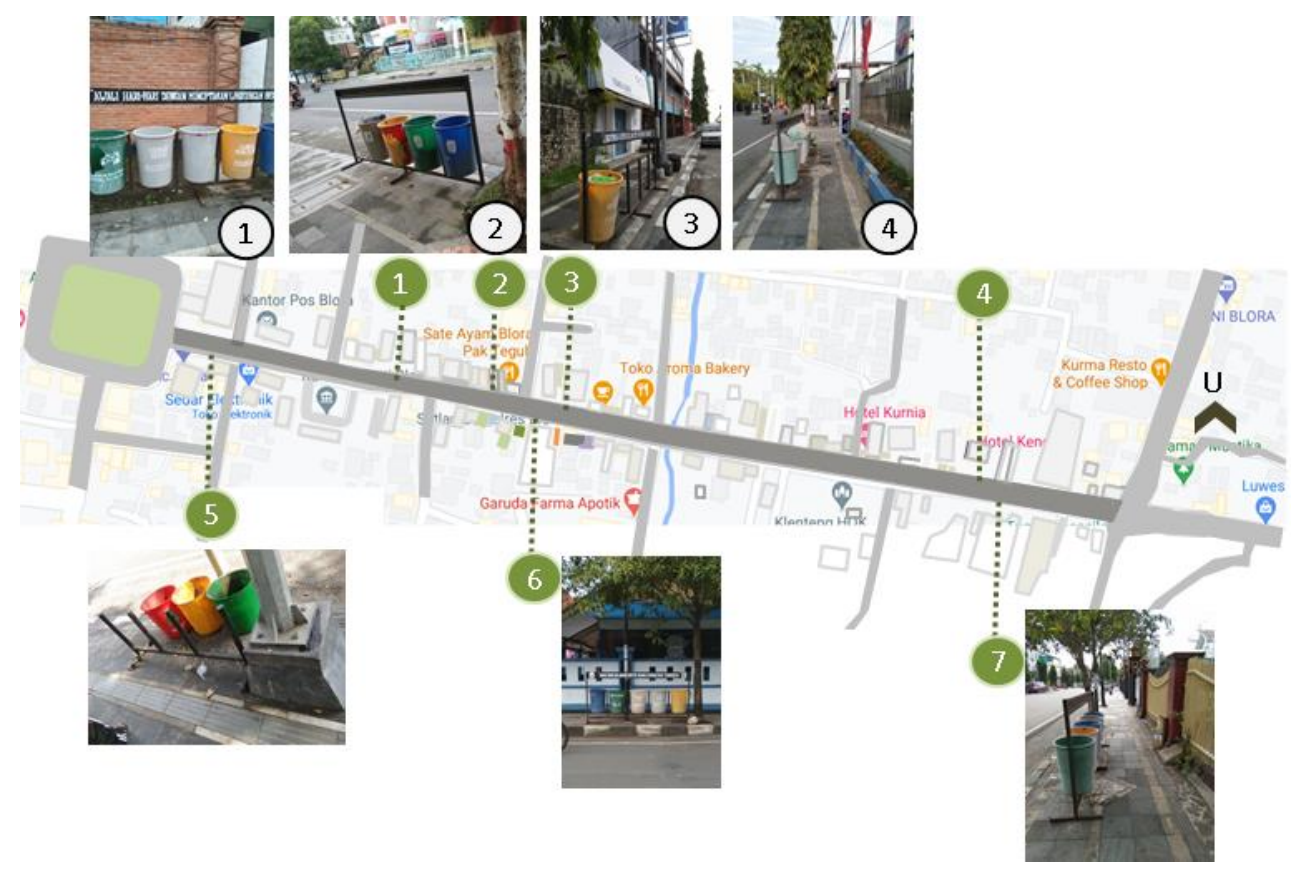

Gambar 6. Persebaran tempat sampah pada eksisting koridor Jalan Pemuda

Sumber : dokumentasi pribadi, google maps dan olahan penulis, 2021

Tempat sampah yang berada di sepanjang koridor Jalan Pemuda tidak terlalu banyak, pada tempat sampah no 1 berada di depan Rumah Wakil Bupati Blora, pada tempat sampah no 2 berada di depan toko bahan bangunan Logam Jaya, tempat sampah ke 3 berada di depan PAUD 123 , tempat sampah ke 4 berada di depan Bank BPD Jateng, tempat sampah ke 5 berada di samping Bank BRl,tempat sampah ke 6 berada di depan POLANTAS Kabupaten Blora dan posisi tempat sampah ke 7 berada di dekat Gereja Paus X (gambar 6). Sebagian besar kondisi tempat sampah telah rusak dan sudah tidak ada penutup tempat sampahnya, kondisi tempat sampah paling baik yaitu no 6 , yang berada di depan Bank BPD Jateng. Jarak antar tempat sampah pada sisi utara cukup jauh terutama letak tempat sampah nomor 3 ke nomor 4, sedangkan jarak tempat sampah nomor 1,2 dan 3 cukup dekat. Pada sisi selatan koridor Jalan Pemuda, hanya terdapat 3 tempat sampah, yang jaraknyaa cukup jauh .

PAWON: Jurnal Arsitektur, Nomor 01 Volume VI, Januari - Juni Tahun 2022, ISSN 2597-7636 


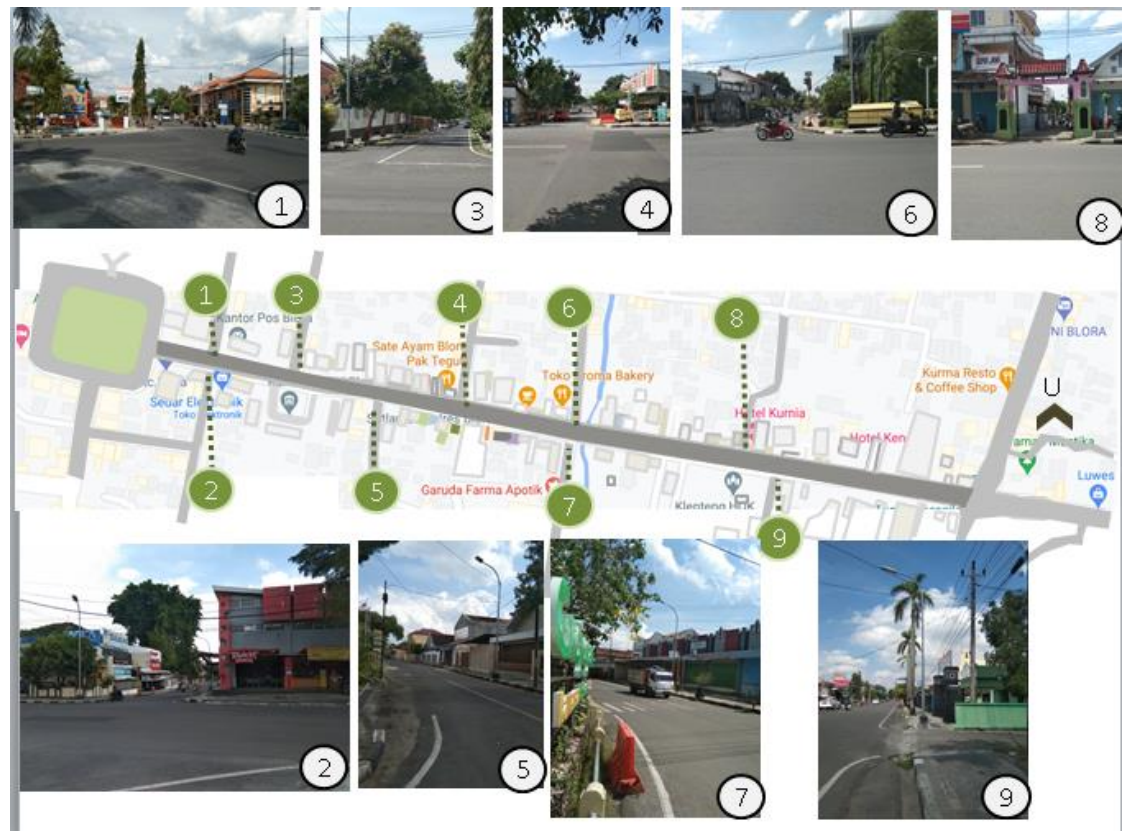

Gambar 7. Titik Persimpangan di koridor Jalan Pemuda Blora Sumber : dokumentasi pribadi, google maps dan olahan penulis, 2021

Pada Koridor Jalan Pemuda Blora terdapat beberapa titik persimpangan, pada titik persimpangan ke 1 dan 2 berada paling dekat dengan alun-alun Blora yaitu pada sebelah Timur alun-alun, pada persimpangan ini berupa titik perempatan. Persimpangan ke- 3 berupa pertigaan jalan, dimana pada persimpangan ini terdapat fungsi perdagangan dan jasa. Pada titik persimpangan ke-4 berupa pertigaan, dimana pada sekitar persimpangan ini didominasi fungsi perdagangan dan jasa. Pada titik persimpangan ke-5 berupa pertigaan, dimana terdapat fungsi perkantoran, perdagangan dan jasa serta hunian. Pada persimpangan ke-6 dan 7 merupakan perempatan, dimana didominasi fungsi perdagangan dan jasa. Pada titik persimpangan ke-8 berupa pertigaan jalan, yang menghubungkan koridor utama Jalan Pemuda menuju ke permukiman penduduk (gambar 7). Sedangkan pada titik persimpangan ke-9, merupakan pertigaan menuju permukiman penduduk. 


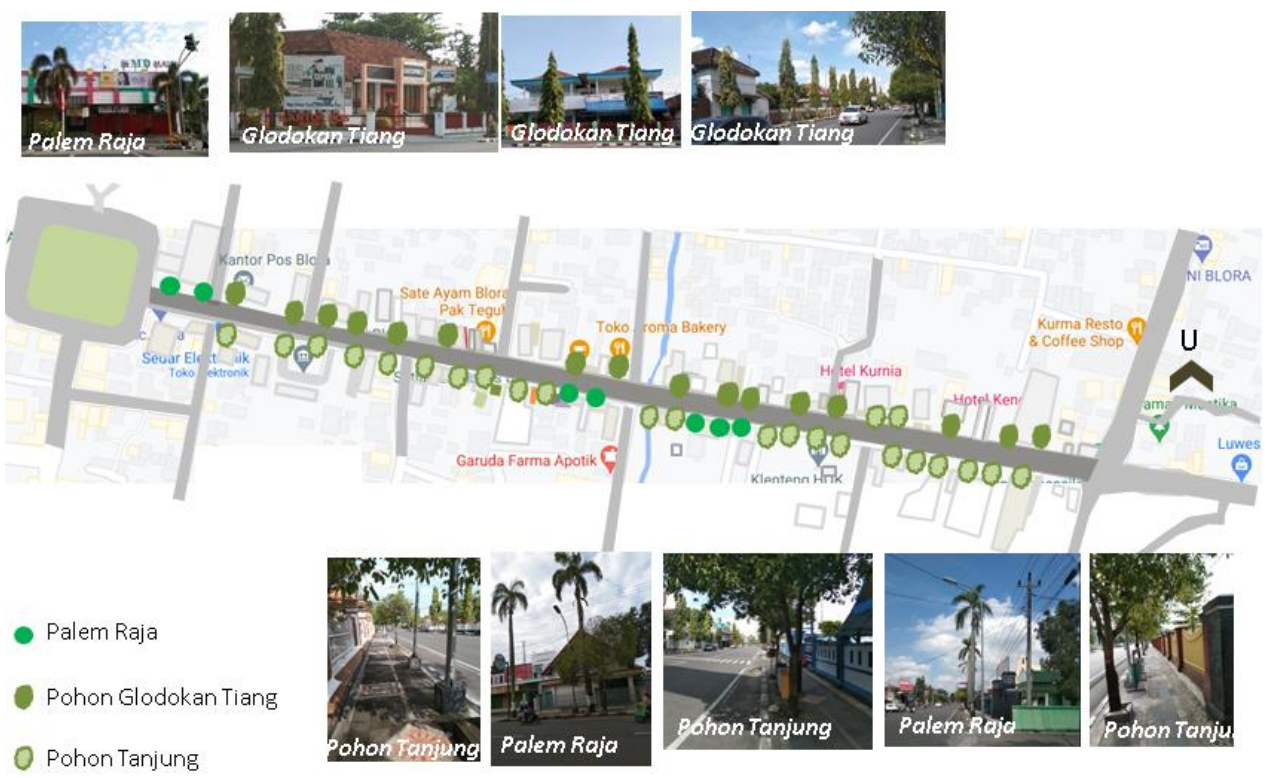

Gambar 8. Persebaran Vegetasi di koridor Jalan Pemuda Blora Sumber : dokumentasi pribadi, google maps dan olahan penulis, 2021

Jenis pohon yang berada di sepanjang jalan Pemuda antara lain; Palem Raja, Glodokan Tiang dan Tanjung. Pada Jalan Pemuda sisi utara didominasi oleh Pohon Glodokan Tiang yang berada di sepanjang jalur pejalan kaki , dengan ketinggian pohon sekitar 4 sampai 5 meter, selain itu, pada sisi selatan terdapat Palem Raja yang berada di depan MD mall (dekat dengan alun-alun Blora). Pada sisi utara pohon didominasi oleh Pohon Tanjung yang berada di sepanjang jalur pejalan kaki, dan terdapat juga Pohon Palem Raja yang berada di depan Kodim Blora ,serta pohon Palem Raja di depan rumah warga (gambar 8).

Jadi jenis pohon didominasi oleh Pohon Glodokan Tiang (berada pada koridor Jalan Pemuda sisi utara) dan Pohon Tanjung (berada pada koridor Jalan Pemuda sisi selatan). Ketika siang hari pada sisi utara terasa lebih panas, jika sedang berjalan di jalur pejalan kaki, karena didominasi Pohon Glodokan Tiang yang memiliki bentuk vertikal ke atas dan tidak rindang. Sedangkan pada sisi selatan, terasa lebih sejuk, karena didominasi oleh Pohon Tanjung, yang memiliki bentuk lebih lebar, daunnya cukup lebat, sehingga terasa lebih rindang (gambar 8). 


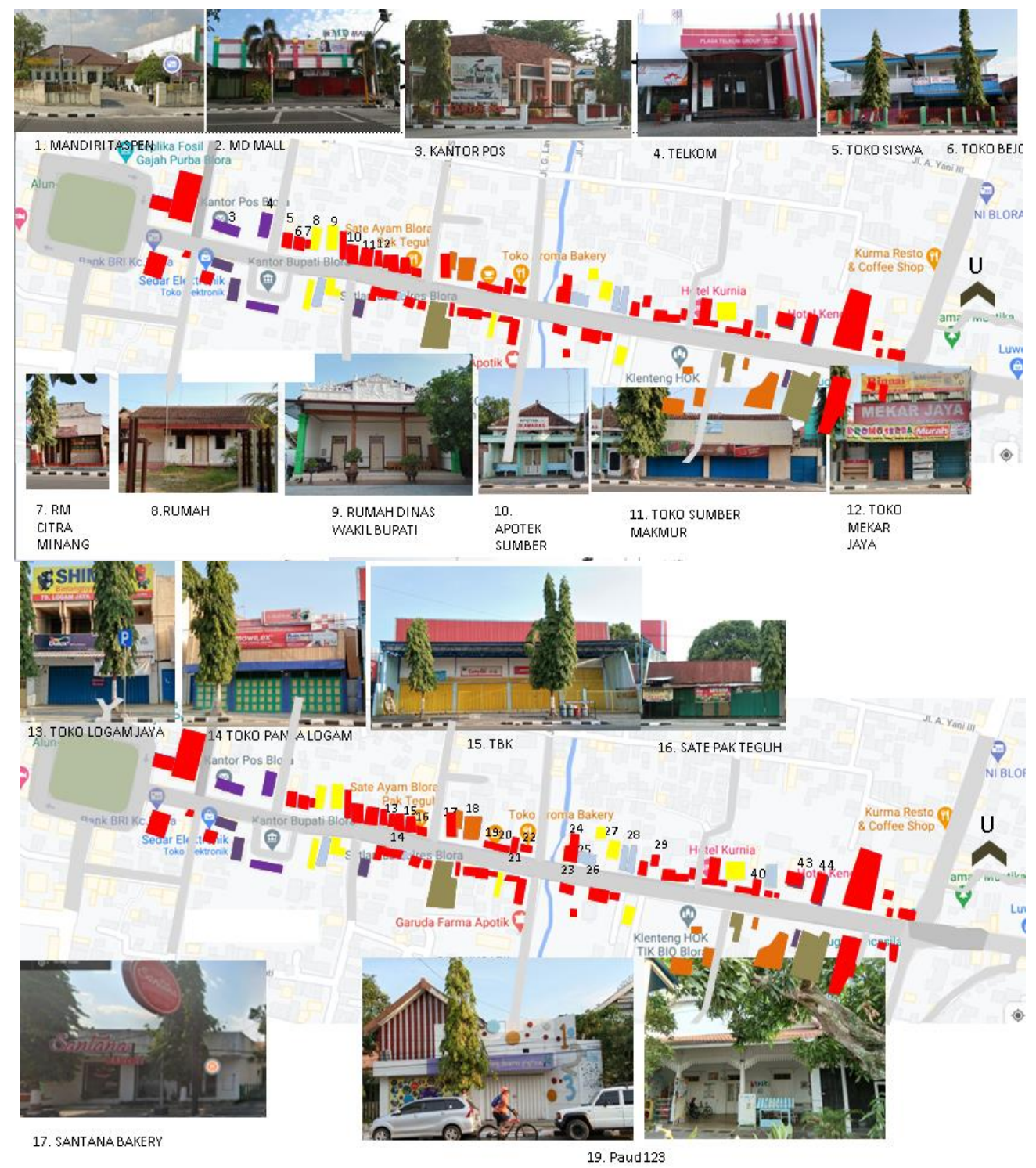

Gambar 9. Papan nama di koridor Jalan Pemuda Blora Sisi Utara Sumber : dokumentasi pribadi, google maps dan olahan penulis, 2021

Signages nama toko pada koridor sisi utara sebagian besar, berupa baliho menempel pada atap dan dinding bangunan. Selain itu terdapat pula papan nama yang berbahan akrilik seperti pada Bank dan Toko Kue Santana. Papan nama toko atau bangunan yang berbahan baliho kurang menarik secara visual, oleh sebab itu diperlukan penataan papan nama bangunan, yang dapat mencerminkan visual image kawasan (gambar 9).

PAWON: Jurnal Arsitektur, Nomor 01 Volume VI, Januari - Juni Tahun 2022, ISSN 2597-7636 


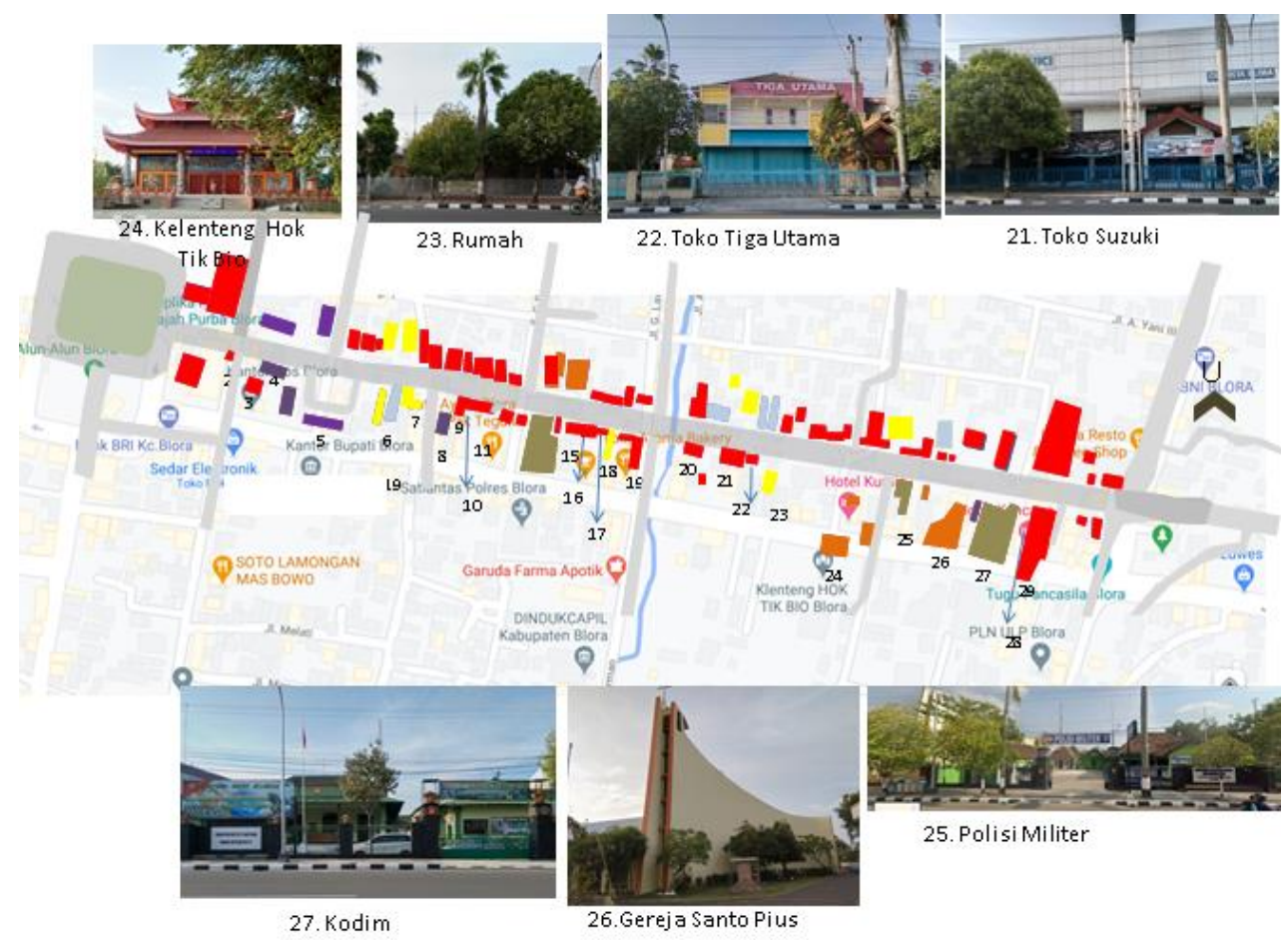

Gambar 10. Papan nama di koridor Jalan Pemuda Blora Sisi Selatan Sumber : dokumentasi pribadi, google maps dan olahan penulis, 2021

Signages nama toko pada koridor sisi selatan sebagian besar, berupa akrilik (pada fungsi Bangunan Pemerintahan, Bangunan Peribadatan dan Pelayanan Sosial, serta pada showroom motor, sedangkan pada ruko maupun toko yang lebih kecil, papan nama berupa baliho menempel pada atap dan dinding bangunan. Papan nama toko atau bangunan yang berbahan baliho kurang menarik secara visual, oleh sebab itu diperlukan penataan papan nama bangunan, yang dapat mencerminkan visual image kawasan (gambar 10).

Pada eksisting streetscape Jalan Pemuda masih kurang optimal, sehingga diperlukan penataan streetscape koridor Jalan Pemuda yang memiliki benang berah dengan bangunan-bangunan lama yang ada disekitarnya, antara lain; penataan bench, lampu taman, tempat sampah, signages (nama jalan, dan nama toko), serta guiding block yang mengutamakan kekhasan Blora yaitu sebagai penghasil kayu jati serta motif batik daun jati sebagai ornamen pelengkap street furniture. Kualitas streetscape sangat penting untuk meningkatan karakter kawasan, karena pada Koridor Jalan Pemuda merupakan kawasan utama di Kota Blora

PAWON: Jurnal Arsitektur, Nomor 01 Volume VI, Januari - Juni Tahun 2022, ISSN 2597-7636 
kerena terdapat fungsi vital seperti kantor pemerintahan, sosial, perdagangan dan jasa, serta hunian.

\section{KESIMPULAN}

Koridor jalan Pemuda merupakan koridor utama di Kota Blora, akan tetapi kualitas fisik streetscape masih kurang optimal. Selain itu, streetscape koridor Jalan Pemuda masih kurang menampilkan identitas kawasan, seperti kurangnya perabot jalan yang mampu merepresentasikan karakter kawasan, dan juga kurangnya elemen perabot ruang, seperti; tempat sampah, bangku taman atau bench, kurangnya guiding blok, signages, fasilitas bersepeda, public art sehingga sehingga diperlukan penataan streetscape koridor Jalan Pemuda untuk meningkatkan kualitas koridor melalui penataan streetscape yang memiliki benang berah dengan bangunan-bangunan lama yang ada disekitarnya (bangunan peninggalan arsitektur Kolonial, dan arsitektur Cina.)

\section{Saran}

Diperlukan redesain streetscape koridor Jalan Pemuda, serta peran serta dari pemerintah Kabupaten Blora untuk mewujudkan streetscape yang dapat merepresentasikan karakter kawasan.

\section{DAFTAR PUSTAKA}

Anugrah, Anisa P. (2015). Preferensi masyarakat dalam menikmati streetscape perkotaan yang ideal. Prosiding Temu IImiah IPLBI 2015, B 135140.

Ismail ,W.N., Ja'afar, N. , Harun,N.Z. (2019). Historic Streetscape Characterization:Exploring the Evolution of Street in the Malay Royal Town. International Journal of Recent Technology and Engineering (IJRTE), Volume-7 Issue-6S2, April 2019.

Krier, R. (1979) Urban Space (Academy ed). Great Britain: Academy Editions London.

Moughtin, C (2003). Urban Design: Street and Square. Oxford: An Imprint of Butterworth Heinemann Ltd,Linacre House

Moughtin, Cliff. 1992. Urban Design : Street and Square. Butterworth Architecture : London

Rehan, M.R. (2013). Sustainable streetscape as an effective tool in sustainable urban design. Housing and Building National Research Center (HBRC) Journal (2013) 9, 173-186

Rizqiyah, Fardilla. (2016). Arahan Disain Fasad Koridor Jalan Songoyudan untuk Memperkuat Citra Visual pada Area Perdagangan Bersejarah di Surabaya. EMARA Indonesian Journal of Architecture Vol 2 No 1 - Agustus 2016. 
Utomo, H.P., Fairuz, Mutia. (2018). Streetscape sebagai Pembentuk Karakter Kawasan,Studi Kasus : Jalan Rungkut Madya Surabaya. Atrium Jurnal Arsitektur, 4 (2), 117-128.

Wardiningsih, S., Putra,P.T., et all. (2018). Streetscape Beautification, Penggunaan Patung Pada Lanskap Jalan Di Provinsi Bali. Jurnal KRAITH-Teknologi, Vol. 2, No. 2,Juli 2018.

Wulanningrum, S.D., Sabtalistia,Y.A. (2021). Tipologi Fasad pada Koridor Jalan Pemuda Sisi Selatan Blora. Jurnal Pawon Vol. 5 No.1. 